\title{
Korelasi Kemampuan Berpikir Tingkat Tinggi dan Prestasi Belajar Siswa MAN 3 Yogyakarta
}

\author{
Deny Sutrisno ${ }^{1}$ dan Heri Retnawati ${ }^{2}$ \\ ${ }^{1}$ STIKES Harapan Ibu Jambi, ${ }^{2}$ Universitas Negeri Yogyakarta \\ Email: ${ }^{1}$ denysutrisno@gmail.com, ${ }^{2}$ retnawati_heriuny@yahoo.co.id
}

\begin{abstract}
Abstrak
Tujuan Penelitian ini adalah untuk mengetahui hubungan antara kemampuan berpikir tingkat tinggi dan prestasi belajar siswa.Penelitian ini adalah eksperimen semu.Penelitian ini dilakukan dari tanggal 18 Februari 2015 sampai dengan 4 April 2015.Penelitan dilakukan di MAN 3 Yogyakarta. Sampel penelitian ini adalah siswa kelas X MIA 3 dan X MIA 4 di MAN Yogyakarta 3 yang terdaftar pada Semester Genap Tahun Ajaran 2014/2015 yang berjumlah 61 orang. Sampel dipilih dengan carapurposive sampling. Korelasi hasil tes kemampuan berpikir tingkat tinggi dan hasil belajar siswa diuji menggunakan uji korelasi pearson product moment. Hasil uji korelasi pearson product moment didapatkan nilai $\mathrm{r}$ adalah 0,69 dengan signifikansi nilai 0,0 . Hal ini menunjukkan bahwa antara kemampuan berpikir tingkat dan prestasi belajar terdapat korelasi yang positif.
\end{abstract}

Kata Kunci: Berpikir Tingkat Tinggi, Prestasi Belajar Siswa, Geometri.

\section{Correlation of Higher Order Thinking Skills and Learning Achievements of Students in MAN 3 Yogyakarta}

\begin{abstract}
The aims of this research is to know the correlation between the higher order thinking skills and learning achievements of students. This research was quasi experiment. This research was conducted from Februari $18^{\text {th }}$ until April $4^{\text {th }}$ at 2015. The research carried out in MAN 3 Yogyakarta. The sample of this research is 61 students of X MIA 3 and X MIA 4 in the MAN 3 Yogyakarta whose registered on the even semester academic years 2014/2015. Sample was selected with purpose sampling. The correlation between the result of higher order thinking skills test and learning achievements of students tested using pearson product moment correlations test. The result of correlation test is obtained a value of $r$ was 0.69 with significance value of 0.0. this shows that between the higher order thinking skills and learning achievement there is a positive correlation.
\end{abstract}

Keywords: higher order thinking, student's learning achievement, geometry

\section{PENDAHULUAN}

Pendidikan selalu menjadi pembahasan aktual di mata dunia.Berbagai metode, model, media, dan strategi belajar dikembangkan sedemikian hingga untuk menunjang era globalisasi. Pasalnya pada era globalisasi ini, kebutuhan akan sumber daya manusia yang mumpuni menjadi dasar utama pembangunan terutama untuk menghadapi MEA (Masyarakat ekonomi Asean).

Salah satu modal terpenting yang dimiliki manusia adalah kemampuan berfikir tingkat tinggi.Kemampuan ini dibutuhkan untuk bekerja dan memikirkan segala sesuatu untuk kemajuan peradaban manusia.Berpikir menjadi hal terpenting yang harus dilatih dan diasah sejak dini.Kemampuan berfikir tingkat tinggi dapat ditingkatkan dengan peranan teknologi 
(Yaniawati, 2013). Sekolah sebagai wadah resmi pemerintahan memiliki peran besar dalam mewujudkan dan meningkatkan kualitas pendidikan.

Mutu pendidikan dapat dilihat dari hasil belajar di sekolah.Hasil belajar tersebut dapat berupa aspek kognitif, seperti kemampuan berpikir tingkat tinggi dan prestasi siswa.Selain hasil belajar berupa prestasi belajar yang sementara, hasil belajar jangka panjang juga diperlukan untuk mutu pendidikan.Kemampuan berfikir tingkat tinggi memiliki banyak hubungan dengan kecerdasan lain diantaranya adalan kecerdasan emosional (Rosiana, Suryawati, \& Nursal, 2015). Kemampuan berfikir itngkat tinggi akan memiliki korelasi penting dengan prestasi siswa (Ramos, Dolipas, \& Villamor, 2013). Kemampuan berpikir tingkat tinggi akan membuat siswa memiliki kemampuan untuk menghadapi permasalahan yang lebih kompleks dari permasalahan biasa. Kemampuan berfikir tingkat tinggi dapat berkembang seiring dengna kegiatan siswa mengeksplorasi teknologi (Polly, 2011).

Hasil UN 2013 SMA/MA atau sederajat di Kota Yogyakarta menunjukkan bahwa daya serap mata pelajaran matematika pada materi Geometri adalah 58,21. Daya serap materi tersebut menempati jajaran urutan bawah dibanding materi lainnya, yaitu logika matematika $(74,58)$, matriks, vektor dan tranformasi $(74,04)$, lingkaran, suku banyak dan komposisi fungsi $(73,17)$, eksponen, barisan dan deret fungsi $(72,72)$, persamaan dan pertidaksamaan $(68,14)$, kalkulus $(61,79)$, statistika dan peluang $(59,82)$, dan trigonometri $(58,06)$. Oleh karena itu pembelajaran pada materi Geometri memerlukan perhatian khusus.

Tujuan penelitian ini adalah untuk mengetahui apakah ada hubungan antara kemampuan berpikir tingkat tinggi dan prestasi belajar siswa.

Hasil belajar dalam ranah kognitif dapat dilihat dari kemampuan berpikir tingkat tinggi yang diidentifikasikan dengan menggunakan taksonomi kognitif.Taksonomi kognitif adalah sebuah skema yang disusun untuk mengklasifikasikan tujuan instruksional pembelajaran ke dalam berbagai tingkatan kompleksitas(Brookhart, 2010).Banyak tingkatan taksonomi kognitif yang diungkapkan oleh pra ahli.Salah satu taksonomi yang paling dikenal dalam pendidikan adalah Taksonomi Bloom. Bloom menyusun taksonomi kognitif yang dikenal dengan taksonomi bloom menjadi enam kelas besar, yaitu knowledge (mengetahui), comprehension (memahami), application (mengaplikasikan), analysis (menganalisis), synthesis (mensintesis) dan evaluation (mengevaluasi). Masing-masing tingkatan memiliki kompleksitas yang berbeda.mengetahui adalah suatu tingkatan kognitif terendah sedangkan yang tertinggi adalah menganalisis.

Kemudian Taksonomi Bloom direvisi Anderson \& Krathwohl. Anderson \& Krathwohl memberikan revisi untuk tingkatan taksonomi Bloom menjadi enam tingkatan proses kognitif berikut: (1) Remember (mengingat), yaitu mendapatkan kembali pengetahuan yang relevan dari ingatan jangka panjang; (2) Understand (memahami), yaitu menyusun pengertian dari pesan-pesan instruksional, termasuk komunikasi lisan, tertulis dan grafik; (3) Apply (mengaplikasikan), yaitu membawakan atau menggunakan sebuah prosedur pada suatu permasalan. (4) Analyze 
(menganalisis), yaitu membagi materi menjadi bagian-bagian unsur pokok dan menentukan bagaimana bagian yang satu berelasi dengan bagian yang lainnya dan untuk membuat struktur atau tujuan; (5) Evaluate (mengevaluasi), yaitu membuat penilaian berdasarkan kriteria dan standar. (6) Create (menciptakan), yaitu mengatur elemen-elemen menjadi sebuah pola atau sturuktur yang baru. Pengertian kemampuan berpikir tingkat tinggi adalah kemampuan kognitif siswa yang berfungsi dalam tingkatan menganalisis, mengevaluasi dan mencipta.

Kemampuan analisa, evaluasi dan mencipta adalah indikator yang perlu diukur untuk mengukur kemampuan tingkat tinggi siswa (Samritin, Suryanto, \& Mardapi, 2016). Untuk itu diperlukan instrumen yang dapat mengukur ketiga poin di atas.Instrumen tersebut dapat berupa tes kepada siswa.

\section{METODE}

Metode penelitian ini adalah eksperimen semu. Penelitian ini dilakukan dimulai dari tanggal 18 Februari 2015 sampai dengan 4 April 2015.Penelitan dilakukan di MAN 3 Yogyakarta. Sampel penelitian ini adalah siswa kelas X MIA 3 dan X MIA 4 di MAN Yogyakarta 3 yang terdaftar pada Semester Genap Tahun Ajaran 2014/2015 yang berjumlah 61 orang. Sampel dipilih dengan carapurposive sampling. Para siswa diberikan dua jenis tes untuk mengukur kemampuan berpikir tingkat tinggi dan prestasi belajar siswa.

Instrument untuk mengukur kemampuan berpikir tingkat tinggi dan prestasi belajar siswa adalah instrumen tes yang dibuat oleh peneliti dan divalidasi oleh dua orang validator ahli.Validator melakukan pemeriksaan dan mengkoreksi seluruh instrumen yang dibutuhkan untuk mengukur kemampuan berpikir tingkat tinggi dan prestasi belajar siswa.

Ukuran kemampuan berfikir tingkat tinggi dapat dilihat dari kemampuan siswa mengatasi masalah (Abdullah, Abidin, \& Ali, 2015). Untuk menguji kemampuan berpikir tingkat tinggi siswa digunakan instrumen test yang berbentuk essay berjumlah 5 soal. Kisikisi soal instrumen tes kemampuan berpikir tingkat tinggi dapat dilihat pada tabel 1 Sedangkan untuk mengukur prestasi belajar siswa digunakan instrumen tes yang berbentuk pilihan ganda berjumlah 20 soal.Kisi-kisi soal instrumen tes hasil belajar siswa dapat dilihat pada tabel 2.Instrumen penelitian dibuat berdasarkan kompetensi dasar pada materi geometri pada mata pelajaran Matematika.

Tabel 1. Kisi-Kisi Instrumen Tes Kemampuan Berpikir Tingkat Tinggi

Kompetensi dasar

Mendeskripsikan konsep jarak dan sudut antar titik, garis dan bidang melalui demonstrasi menggunakan alat peraga atau media lainnya.

Menggunakan berbagai prinsip bangun datar dan ruangsertadalam menyelesaikan masalah nyataberkaitan dengan jarak dan sudut antara titik, garis dan bidang.

\section{Indikator}

1. Analisis, mampu membedakan atau mengatur konsep.

2. Evaluasi,mampu menilai sesuatu.

3. Mencipta, mampu merencanakan ataumembuat sesuatu. 
Tabel 2. Kisi-Kisi Instrumen Tes Prestasi

\begin{tabular}{|c|c|c|}
\hline Kompetensi dasar & Indikator & No Soal \\
\hline $\begin{array}{l}\text { Mendeskripsikan konsep } \\
\text { jarak dan sudut antar titik, } \\
\text { garis dan bidang melalui } \\
\text { demonstrasi menggunakan } \\
\text { alat peraga atau media } \\
\text { lainnya. }\end{array}$ & $\begin{array}{l}\text { Menentukan jarak antara titik dan titik. } \\
\text { Menentukan jarak titik ke garis. } \\
\text { Menentukan jarak titik ke bidang. } \\
\text { Menentukan jarak dua garis yang } \\
\text { sejajar. } \\
\text { Menentukan sudut antara dua garis } \\
\text { dalam ruang. } \\
\text { Menentukan sudut antara garis dan } \\
\text { bidang pada bangun ruang. }\end{array}$ & $\begin{array}{c}1,2,3 \\
4,5,6 \\
7,8,9 \\
10,11,12 \\
13,14,15 \\
16,17,18\end{array}$ \\
\hline $\begin{array}{l}\text { Menggunakan berbagai } \\
\text { prinsip bangun datar dan } \\
\text { ruangsertadalam } \\
\text { menyelesaikan masalah } \\
\text { nyataberkaitan dengan } \\
\text { jarak dan sudut antara titik, } \\
\text { garis dan bidang. }\end{array}$ & $\begin{array}{l}\text { Menyelesaikan masalah nyata berkaitan } \\
\text { dengan jarak antara titik, garis dan } \\
\text { bidang. } \\
\text { Menyelesaikan masalah nyata berkaitan } \\
\text { dengan sudut antara titik, garis dan } \\
\text { bidang. }\end{array}$ & $\begin{array}{l}19 \\
20\end{array}$ \\
\hline
\end{tabular}

Hasil tes kemampuan berpikir tingkat tinggi dan hasil belajar siswa akan diuji menggunakan uji korelasi pearson product moment. Perhitungan uji korelasi dilakukan menggunakan PSPP free licence software.

\section{HASIL DAN PEMBAHASAN}

Hasil tes kemampuan berpikir tingkat tinggi dan hasil belajar siswa secara deskriptif dapat dilihat pada tabel 3.Siswa yang mengikuti tes sebanyak 61 orang. Rata-rata nilai kemampuan berpikir tingkat tinggi siswa adalah 48,75 sedangkan rata-rata nilai tes prestasi belajar adalah 65,16 .

Tabel 3.Hasil Test Kemampuan Berpikir Tingkat Tinggi dan Prestasi Belajar Siswa

\begin{tabular}{ccc}
\hline & $\begin{array}{c}\text { Kemampuan Berpikir Tingkat } \\
\text { Tinggi }\end{array}$ & Prestasi Belajar \\
\hline Rata-rata & 48,75 & 65,16 \\
Standar Deviasi & 21,01 & 25,62 \\
Variansi & 441,56 & 656,64 \\
Nilai Maksimum Teoritik & 100 & 100 \\
Nilai Minimum Teoritik & 0 & 0 \\
Nilai Maksimum Siswa & 80 & 95 \\
Nilai Minimum Siswa & 0 & 0 \\
\hline
\end{tabular}

Perhitungan uji korelasi pearson product moment dilakukan menggunakan PSPP free licence software. Hasil perhitungan dapat dilihat pada tabel 4. 
Tabel 4. Hasil Perhitungan Uji Korelasi Pearson Product Moment Menggunakan PSPP

\begin{tabular}{cc}
\hline Pearson Correlation & 0,69 \\
Sig. (2 Tailed) & 0,00 \\
N & 61 \\
\hline
\end{tabular}

Hasil uji korelasi pearson product moment didapatkan nilai $\mathrm{r}$ adalah 0,69 dengan signifikasi nilai 0,0. Hal ini menunjukkan bahwa antara kemampuan berpikir tingkat dan prestasi belajar adalah memiliki korelasi positif.

Menganalisis antara konsep pelajaran dan penerapan dalam berbagai soal kerap menjadi problematika siswa.Berbeda soal mereka anggap sebagai permasalahan yang berbeda pula.Dengan demikian siswa bingung bagaimana penyelesaiannya dan berkesimpulan bahwa belajar itu sulit.Sehingga menjadi hal yang wajar jika prestasi belajar pun menurun. Pada penelitian inilah, akan diketahui apakah ada hubungan antara kemampuan berpikir tingkat tinggi dan prestasi belajar siswa.

Berpikir tingkat tinggi terjadi ketika seseorang mengambil informasi baru dan informasi yang tersimpan dalam memori dan saling terhubungkan atau menata kembali dan memperluas informasi ini untuk mencapai tujuan atau menemukan jawaban yang mungkin dalam situasi membingungkan.Berpikir tingkat tinggi dapat diukur, sehingga bisa dipelajari oleh para pendidik.Berpikir tingkat tinggi dapat diajarkan dengan analisis, yaitu mampu membedakan atau mengatur konsep.Evaluasi, yaitu mampu menilai sesuatu.Mencipta yaitu, mampu merencanakan atau membuat sesuatu.

\section{KESIMPULAN}

Berdasarkan hasil penelitian ini dapat disimpulkan bahwa kemampuan berpikir tingkat tinggi siswa memiliki korelasi positif dengan prestasi belajar siswa.

\section{DAFTAR PUSTAKA}

Abdullah, A. H., Abidin, N. L. Z., \& Ali, M. 2015. Analysis of Students??? Errors in Solving Higher Order Thinking Skills (HOTS) Problems for the Topic of Fraction. Asian Social Science, 11(21): 133. Retrieved from https://doi.org/10.5539/ass.v11n21p133.

Brookhart, S. 2010. How to Asses Higher-Order Thinking Skills in Your Classroom. Alexandria: ASCD.

Polly. 2011. Developing students' higher-order thinking skills (HOTS) through technologyrich tasks. Educational Technology, 51(August), 20-26.

Ramos, J. L. S., Dolipas, B. B., \& Villamor, B. B. 2013. Higher Order Thinking Skills and Academic Performance in Physics of College Students: A Regression Analysis. International Journal of Innovative Interdisciplinary Research, (4), 48-60. Retrieved from https://doi.org/ISSN 1839- 9053

Rosiana, E. R. E., Suryawati, E. S. E., \& Nursal. 2015. Pengembangan Lembar Kerja Siswa Biologi SMA/MA Kelas X dengan Konten Kecerdasan Emosional pada Materi Perubahan dan Pelestarian Lingkungan untuk Meningkatkan Higher Order Thinking 
Skills (HOTS). Jurnal Online Mahasiswa (JOM) Bidang Keguruan Dan Ilmu Pendidikan, 2(2), 1-12. $\quad$ Retrieved from http://jom.unri.ac.id/index.php/JOMFKIP/article/view/6720

Samritin, S., Suryanto, S., \& Mardapi, D. 2016. Developing an Assessment Instrument of Junior High School Students' Higher Order Thinking Skills in Mathematics. Research and Evaluation in Education, 2(1), 92-107.

Yaniawati, R. P. (2013). E-Learning to Improve Higher Order Thinking Skills ( HOTS ) of Students. Journal of Education and Learning, 7(2), 109-120. 